\title{
Women in the boardroom and their impact on climate change related disclosure
}

\begin{abstract}
Purpose - This paper aims to investigate the relationship between gender diversity and the Carbon Disclosure Project (CDP) score/index. Specifically, the study describes extant research on theoretical perspectives, and the impact of women on corporate boards (WOB) on carbon emission issues in the global perspective.

Design/methodology/approach - This study uses the carbon disclosure scores of the Carbon Disclosure Project (CDP) from 2011 to 2013 (inclusive). A total observation for the three year periods is 1175 companies. However, based on data availability for the model, our sample size totals 331 companies in 33 countries with firms in 12 geographical locations. We used a model which is estimated using the fixed-effects estimator.

Findings -The outcomes of the study reveal that there is a positive relationship between gender diversity (WOB) and carbon disclosure information. In addition to establishing a relationship between CDP score and other control variables, this study also found a relationship with Board size, asset size, energy consumption, and Tobin's $Q$, which is common in the existing literature.
\end{abstract}

Research limitations/implications -The limitations of the study mostly revolve around samples and the time period. To further test the generalizability and cross-sectional validity of the outcomes, it is suggested that the proposed framework be tested in more socially responsible firms.

Practical implications -There are increasing pressures for WOBs from diverse stakeholders, such as the European Commission, national governments, politicians, employer lobby groups, shareholders, Fortune and FTSE rankings and best places for women to work lists. The study offers insights to policy makers implementing gender quota legislation.

Originality/value -The study has important implications for putting into practice good corporate governance and in particular, gender diversity. The outcomes of our analyses advocate that companies that included women directors and with a smaller board size may expect to achieve a higher level of carbon emission performance and to voluntarily disclose the level of carbon information assessment requested by the CDP.

Keywords Climate change, Carbon disclosure project, GHG, Corporate social responsibility, Women on corporate board

Paper type Research paper

\section{Introduction}


There is growing scientific evidence that carbon emissions are the major cause of global warming, which is a serious threat to the quality of human lives (Lash and Wellington, 2007; Allen et al., 2009; Luo, et al., 2012; Luo and Tang, 2014a; Luo and Tang, 2014b). According to the Intergovernmental Panel on Climate Change (IPCC), average temperatures have already risen by $0.85^{\circ} \mathrm{C}$ since 1880 (Luo and Tang, 2016). We are expected to experience significant increases in surface temperatures and atmospheric $\mathrm{CO}_{2}$ concentrations. In addition, sea levels are projected to rise between 26 and 81 centimetres by 2100 (IIPCC, 2013). Therefore, corporations are expected to play an important role in stabilising climate change and in the control of greenhouse gas (GHG) emissions (interchangeably use the terms as 'carbon', 'carbon dioxide $\mathrm{CO}_{2}$ '). This is essential for sustainable corporate development. Therefore, there is a growing demand for carbon-related information (Organisation for Economic Co-operation and Development [OECD], 2010; Rankin et al., 2011; Luo and Tang, 2016). A variety of actions have been taken around the world to deal with GHG emissions. Some examples are the European Emissions Trading Scheme (EU ETS), the Kyoto Protocol, Australian Emissions Trading Scheme (AETS) and Carbon Disclosure Project (CDP).

This study explores the impact women on the corporate board of directors have on climate disclosure. It uses CDP's, a nongovernmental and not-for-profit organization, 'carbon-related disclosure score (CDS)' in determining the extent to which global companies proactively address the climate change agenda and whether board diversity has a positive impact on this reporting process. The importance of this study derives from competing views such as women on corporate board can bring distinctive management style to improve board's effectiveness, or women's limited experience in leadership positions could have negative effect for board's work practices (Nielsen and Huse, 2010). The strategic decision-making literature recognizes the composition of boards of directors as an important factor in corporate decision making (Post et al., 2011; Fuente et al., 2017). Surveys have revealed that 
a significant majority of board members view their role as determining the strategic direction of the company (Demb and Neubauer, 1992). The role of women in board positions is also receiving increased attention in recent decades (Daily et al., 1999; Hillman et al., 2007; Terjesen et al., 2009; Nielsen and Huse, 2010; Fernandez-Feijoo et al., 2014; Ben-Amar et al., 2015; Liao et al., 2015; Hoang et al., 2016). The literature has shown that women usually have a higher perception of risks and have been socialised to care for the needs of others. Based on these qualities, they have a closer feeling towards social responsibility (Ciocirlan and Pettersson, 2012). Women are also more likely to provide socially desirable responses and to be more sensitive to ethical issues than men (Bernardi, 2006). In order to understand the effect that women have on boards, it is important to consider not only their presence, but also their number. Given this fact, researchers (Prado-Lorenzo and Garcia-Sanchez, 2010; Lio et al., 2014; Ben-Amar, et al., 2015) have examined the effect of gender diversity on GHG emissions disclosures with mixed results.

For example, Prado-Lorenzo and Garcia-Sanchez (2010) do not find any effect of gender diversity in the boardroom on GHG disclosures based on a sample of 283 companies for the CDP 2008 project. In contrast, Liao et al. (2014) report a positive effect of female presence on 2010 carbon disclosures in the United Kingdom (UK), and Ben-Amar et al. (2015) find that female boardroom participation is positively related to the voluntary disclosure of climate change information based on a sample of Canadian firms over the 2008-2014 period. They also reveal that board gender diversity with more than two women directors influences board disclosures on GHG emission levels and climate change strategies. However, our study is different from the previous three studies with regards to the extended sample and global perspective. It, therefore, contributes to the understanding of whether women can influence the board by addressing current climate change risk issues as pressures come from different 
stakeholders such as regulatory authorities, policy makers, international organisations and the media.

This study contributes to the literature on board diversity and climate change risk discourse in several ways. First, we analyse the relationship between female representation on corporate boards and CDP scores from an international context covering 33 countries, since it is the firm's decision to voluntarily disclose climate change related risk information and opportunities that have been requested by CDP as an institutional stakeholder. Institutional investors are actively seeking change on board diversity and climate change disclosure. Therefore, they need to explore how board gender diversity may shape corporate response to institutional investors' demands for increased public reporting about climate change risks (Ben-Amar et al., 2015). This is important because GHG emissions and public disclosure to investors can be assumed as a first step toward addressing climate change issues and reducing the company's carbon footprint (Hoffman, 2005; Kolk and Pinkse, 2007; Reid and Toffel, 2009; Bocken and Allwood, 2012). Although Ben-Amar et al. (2015) examine this issue in the sample of 541 Canadian firms, our investigation is not limited to a specific country. By contrast, our study of climate change is global in nature.

Second, the study emphasises that an effective diversified board is necessary to address issues raised by various stakeholders in relation to climate change risk disclosure. This concept contributes to the corporate governance literature since we investigate firm level board diversification. Corporate governance mechanisms encourage firms to disclose voluntary information about carbon emissions. From a study of global companies and different economic environments, it is imperative to observe whether corporate governance mechanisms address carbon emission disclosure and to what extent they do this. Third, our paper also contributes to the voluntary disclosure literature on climate change disclosure scores by CDP rather than general sustainability disclosures. The CDP data are derived from 
a set of complete questionnaires (Luo et al., 2012), while sustainability disclosure data relies on annual reports, sustainability reports, environmental reports and company websites (Post et al., 2011; Fernandez-Feijoo et al., 2014; Seto'-Pamies, 2015). The CDP report is a standalone carbon statement that requires the company to provide comprehensive and specific carbon information (Luo and Tang, 2014). In the absence of internationally accepted standards, the CDP has adopted a set of rules that participating firms must follow and thus significantly reduces the opportunity for managers to manipulate carbon data (Luo and Tang, 2014). Finally, the findings of the study may contribute to the understanding of regulators and policy makers about taking steps forward in accommodating women directorship in the board and to what extent. This will provide firms with direction, either mandatorily or voluntarily to include women in the board of directors. For example, in the UK, FTSE 100 boards should aim for a minimum of $25 \%$ female representation by 2015 . The European Commission has set a $40 \%$ target for female representation by 2020, while the Australian ASX Corporate Governance Council recommends that companies establish a policy concerning diversity and disclose in their annual reports, the proportion of women in the whole organisation, in senior executive positions and on the board (Ben-Amare et al., 2015).

Within this context and based on the discussion above, the present study develops the following hypotheses in terms of management's motivation about carbon emission disclosure and the strategies to deal with climate change in response to the CDP survey. This study uses the lens of gender to explore the role of director preferences in the selection of corporate strategies with regard to corporate climate change risk issues.

\section{Theoretical orientations}

The social responsibility of businesses has been influenced by various theories (Carroll and Buchholtz, 2000). In this study, we have developed our theoretical orientations in the lens of corporate governance and diversity as well as stakeholder theory and resource dependence 
theory. In other words, we need to explore how diversity especially on the number of women on boards contributes to corporate governance mechanism and also how it reflects to the CDP score. In recent years, corporate governance reforms emphasise diversity in boardrooms (Davies Report, 2015; European Commission, 2014; Higgs Report, 2003). Also increased demand for gender diversity on boards has led researchers to examine the factors which influence the presence of women directors in the boardrooms (Saeed et al. 2016). The presence of female directors on boards can reinforce mechanisms of stakeholder engagement (Al-Shaer and Zaman, 2016) and increase the credibility of corporate reports (Manetti and Toccafondi, 2012). The arguments for increasing the number of women on boards can be grouped into three categories: theoretical, moral and business arguments (Walt and Ingley, 2003). In terms of theoretical arguments for board diversity are based on the question of whom the board should report to, whose interests it protects and by whom the board can be held accountable (Lückerath-Rovers, 2009), which include agency theory (Jensen and Meckling, 1976), stakeholder theory (Freeman, 1984), resource dependence theory (Pfeffer and Salancik, 1978) and stewardship theory (Donaldson and Davis, 1991).

The above theories have different approach on the role of the board (monitoring versus advice, shareholders versus stakeholders), and the importance of the independency of directors. So, diversity is argued to improve independency while people with a different gender, ethnicity or cultural background might ask questions. Therefore, gender is argued, as one of the most-debated diversity issues in the corporate governance literature, and, given that women are expected to offer value that is different from that of men, numerous calls have been made to increase the number of women on boards (Singh et al. 2008; Terjesen et al. 2009) be posed by directors with more traditional backgrounds (Carter et al., 2003). Regarding moral argument, it is based on the social responsibility of companies and their boards such as being a good corporate citizen (Walt and Ingley, 2003; Lückerath-Rovers, 
2009; Carroll, 1991, Galbreath, 2016). The moral obligations of businesses to society begin with its obligations to uphold the perfect rights afforded in its stakeholder relationships (Brown and Forster, 2013). Carver (2002) argues that the rationale for diversity in the boardroom lies within the concept of ownership and the [moral] obligation of boards in their stewardship role. Representing ownership requires that a board represent the diversity within the ownership (Walt and Ingley, 2003). According to Carver (2002), in the bracket of humankind and human opinion in the ownership to find its way into governance, which constitute the board to be a reflection of the ownership as social justice is a dominant governance value. Thus, the stakeholder theory has grown into a theory for both corporate governance and corporate social responsibility (Kaptein and Wempe, 2002, Walt and Ingley, 2003. Finally, the improvement of company performance is used as a business argument for diversity. Diverse groups consider a greater range of perspectives and generate more highquality solutions. This could ultimately lead to higher company performance and company value (Burgess and Tharenou, 2002; Singh and Vinnicombe, 2004; Kang et al., 2007). Lückerath-Rovers (2009) argue that both stakeholder theory and resource dependence theory question who should serve on corporate boards in order to give the board legitimacy, and to what extent this contributes to corporate governance and thus, a brief discussions on theoretical orientations is made in the following paragraphs.

\subsection{Stakeholder theory}

The underlying rationale behind GHG emission disclosures has been enunciated under various socio-political and non-social political theories (Patten, 2002), of which stakeholder theory is particularly appropriate. Researchers advocate that stakeholder theory is fundamental to the study of business and society (Galbreath, 2016; Liao et al., 2015; Clarkson, 1995; Donaldson and Preston, 1995; Freeman, 2014). Stakeholder theory is based on the premise that an organisation has many stakeholders rather than a single group of 
shareholders, or groups of financial stakeholders, such as creditors (Momin, 2013). As an organisation needs to manage its relationship with many stakeholder groups that affect, or are affected by, its business decisions (Clarkson, 1995; Freeman, 1984), therefore, such relationships produce different arguments, leading to a number of variations of the stakeholder theory (Momin, 2013). The literature discusses three main variants of stakeholder theory: a normative (ethical), a managerial (instrumental) and the descriptive versions. (Donaldson and Preston, 1995; Jamali, 2008). The normative variant suggests that management might address stakeholder concerns from an accountability perspective, the instrumental and descriptive variants suggest that businesses might manage powerful stakeholders strategically by identifying them with the self-interest of the business (Donaldson \& Preston, 1995; Momin, 2013). Within the stakeholder model, several groups of stakeholders have expressed their concern about the absence of women board directors (Hillman et al., 2007). Moreover, Al-Shaer and Zaman (2016) argued that female directors are more likely to be stakeholder oriented, concerned about ethical practices and socially responsible behaviour and also be inclined to take actions to reduce perceived risks (Adams and Ferreira, 2009; Carter et al., 2003). They find that gender diverse boards are associated with higher quality sustainability reports. Nielsen and Huse (2010) also argued that women on board can reduce the level of conflict and ensure high quality of board development activities and strategic decision.

In the context of this study, Liao et al. (2015) argue that "GHG emissions are ubiquitous and persistent, and the climate-change legislation may influence a firm either directly or indirectly, and favourably or unfavourably" (p. 412). Authors also argue that in order to have far-reaching impact on their future development, firms must make strategic decisions. The extent of a company's social disclosure depends on its social performance (Ullmann, 1985). In this case, social performance refers to an organisation's responses to anticipated or existing 
social demands (Strand, 1983). Managers continually encounter demands from multiple stakeholder groups to devote resources to corporate social responsibility (McWilliams and Siegel, 2001). Hence, stakeholders need to be managed to maintain their continued support and ultimately ensure that corporate objectives and strategic decisions are taken which consider existing social demands as well as recognize the relevance of multiple stakeholders (Donaldson and Preston, 1995; Mitchell et al., 1997; McWilliams and Siegel, 2001). Therefore, this implies that companies have identified their target audience and are providing information that will influence (or distract from) this group (Gray et al., 1996). Moreover, it is argued that organizations could not survive if they were not responsive to the demands of the groups in their environments, who are thus enabled to influence organizational outcomes (Pfeffer and Salancik, 1978). In this case, women are more sensitive to social and ethical issues (Bear et al., 2010; Hafsi and Turgut, 2013; Isidro and Sobral, 2015; Al-Shaer and Zaman, 2016). It is thus likely that due to females' higher concerns for social responsibility issues and greater stakeholder orientation a gender diverse board may affect sustainability reporting quality (Al-Shaer and Zaman, 2016, p. 212) which might have positive impact in the CDP project.

\subsection{Resource dependence theory}

Resource dependence theory offers the rationale for the board's function of providing critical resources to the firm including legitimacy, advice, and counsel (Hillman and Dalziel, 2003). These board resources offer the corporation support in understanding and responding to its environment (Boyd, 1990) that can help it better manage CSR issues (Bear et al., 2010). Moreover, resource dependence has two major implications regarding boards of directors. First, composition of the board should be affected by environmental pressures and demands. Second, differences in board composition should affect a firm's performance (Boyd, 1990). As we are concerned in this study environmental issue, i.e. climate change, therefore, our 
discussion is limited to the first concern. Indeed, from the perspective of resource dependence theory, the board of directors is a primary linking mechanism for connecting a firm with external resources (Hillman et al., 2007). In addition, as per stakeholder model, the board of directors might be a linking mechanism for connecting a firm with external stakeholders (Lückerath-Rovers, 2009).

In the context of resource dependence theory, using the board of directors as a linkage mechanism towards stakeholders provides companies with at least four benefits (Pfeffer and Salancik, 1978, p.145): firstly, linkage may provide the organisation with useful information, secondly, linkage provides a channel for communication purposes, thirdly, linkage is an important step in obtaining commitments of support from important elements of the environment and fourthly, linkage has a value in legitimizing organisations (LückerathRovers, 2009). Hillman et al., (2007) add that legitimacy and conformity to societal expectations are considered key components of organisational survival.

In this study, the focus will be on the fourth benefit of board linking: providing legitimacy to an organisation. Resource dependence argues that external pressures- such as competition, regulation, and social forces-will cause firms to seek out environmental linkage which is measured by board size (Boyd, 1990). In this case, CDP scores might have influence from the board's role as corporate boards do respond to environmental pressures and demands. Moreover, board's influence on CSR is facilitated by the activities of monitoring and support (Hillman and Dalziel, 2003), which are dependent upon specialised human capital resources. Therefore monitoring at the board level is an activity that requires the oversight of management, corporate resources, and firms' outcomes. However, effective boards do more than monitoring; they also advise. Their advice can assist management to make high-quality decisions (Hillman and Dalziel 2003). The presence of women directors has been linked to various outcomes and having women on boards does exert some influence on non-financial 
performance and in particular CSR (Stanwick and Stanwick 1998; Wang and Coffey 1992; Williams 2003; Bernardi and Threadgill, 2010; Smith et al., 2001; Siciliano, 1996). In addition, women are more oriented toward supporting and maintaining relationships than men (Hisrich and Brush 1984), are strong in the areas of idea generation and innovation (Rosener 1995), and have been noted as having higher moral and ethical atonement than men (Betz et al. 1989). Therefore, women through their specialised human capital, bring a high level of skill at idea generation and innovation (Triana et al., 2013; Torchia et al. 2011), both of which would be expected to help boards to make appropriate and necessary decisions to improve CSR. Here, the resources offered by women are expected to help boards, enabling them to innovate more readily around CSR initiatives. The resources of women on boards are also expected to be engaged to carefully consider and respond to stakeholders who have varied interests in the firm, such as environmental and social interests (Galbreath, 2016).

\subsection{Agency theory}

Based on Jensen and Meckling (1976)'s agency theory, Barnea and Rubin (2010) consider CSR engagement as a principal-agent relation between managers and shareholders ( $\mathrm{Li}$ et al., 2016). Moreover, agency theory explains how principals efficiently organise exchanges with agents by employing mechanisms - incentive alignment and monitoring - in appropriate combinations (Eisenhardt, 1989; Jensen \& Meckling, 1976) and also hold their organisations to higher ethical standards (Pan and Sparks 2012). However, in order to avoid the agency conflict, the management should avoid the cost of dealing with environment problems, namely, reducing high-energy consumption, activities to reduce GHG emission, and air and water treatment before being released to the environment (Terjesen et al., 2016). In other words, agents or the firm management would carry out such activities to benefit them, however, in return, it will be at the cost of the shareholders. Firms need to take up activities and initiatives to tackle the known global warming issues and impose solutions to minimize 
the impact on the environment (Amran et al., 2014). Climate change disclosure is one way of providing evidence, which can increase the confidence of the stakeholders. Therefore, the firms should use sustainability reporting to publicise to stakeholders that individual firms are undertaking activities to curb global warming issues (Amran et al., 2014). Hence, to mitigate the agency dispute between the agent and principal, additional disclosure in reporting will ease the increasing concern. It is the firms' duty to handle the climate change issue in a more professional manner to avoid an unfavourable image and legal expenses, (i.e. agency cost). There is evidence that boards with more women have greater levels of public disclosure (Gul et al. 2011) and research supports that women's ability to influence board decisions increases with their numbers, particularly boards with more than one woman (Fondas and Sassalos 2000).

\subsection{Discussion on theoretical underpinning}

The above discussion leads us to posit that the CDP's score may be affected by the gender diversity on board under the umbrella of above theories. It is also noted that the current literature emphasises the importance of carbon relevant risk disclosure of firms given the planetary boundaries, which are perceived as resource scarcity (Deegan, 2002; Parker, 2005; Islam and Deegan, 2008; Liao et al., 2015: Guenther et al., 2016). Therefore, it is useful for a firm to be held accountable to the relevant stakeholders who have a stake in knowing how the resources entrusted to a firm are used (Schaltegger and Burritt, 2000), to obtain a "contract to continue its operations" (Deegan, 2002, p. 293). Guenther et al., (2016) discuss another issue of 'stakeholder salience' (Neville et al., 2011) in explaining stakeholder relevance in relation to carbon disclosure. Eesley and Lenox (2006, p. 765) define salience "in terms of whether firms are likely to respond to stakeholder requests for action and by proposing that power, legitimacy, and urgency arise out of the nature of stakeholder-request-firm triplets". Carbon disclosure is a way of satisfying salient stakeholders and reflects an adaptive management 
approach to address a dynamic, multidimensional environment, and an ability to meet social pressure and respond to societal needs (Hackston and Milne, 1996). Moreover, Liao et al. (2015) argue that agency and legitimacy theories, although widely applied, are inadequate to explain GHG-reporting phenomena. Therefore, in this context, stakeholder and resource dependence theories are a more valid theoretical perspective, because the preferences of one interest group with regard to climate-change activities may not be congruent with those of other groups (Liao et al., 2015). Indeed, stakeholders are a common antecedent, moderator or mediator variable (Guenther and Hoppe, 2014) in the related research field of corporate environmental (carbon) disclosure (Clarkson et al., 2008; Huang and Kung, 2010). On the hand, within the framework of resource dependence theory, women on board brings specialised human capital (Miller and Triana, 2013) and help board to address the environmental concern with particular in climate change risk issue in the CDP project.

\section{Related literature and Hypotheses development}

The CDP has made significant contributions in obtaining greater corporate disclosure of risks related to climate change (McFarland, 2009). Its voluntary efforts encourage standardised voluntary reporting for companies to provide investors with relevant information about climate change-related business risk (Kolk et al., 2008). The intention to provide this climate change-related business risk information depends on the board of directors since it is a company's main governance body and acts the entity responsible for safeguarding the interests of the stakeholders in the company by carrying out its duties (Hill and Jones, 1992; Prado-Lorenzo, and Garcia-Sanchez, 2010).

\section{1 Gender diversity}

Diversity is a characteristic of an organization's board of directors, which is related to the existence of differences in its members' traits (Prado-Lorenzo and Garcia-Sanchez, 2010). Gender diversity is one of the more interesting human aspects that has been the focus of 
many studies (Willims, 2003; Nalikka, 2009; Lückerath-Rovers, 2009; Adams, and Ferreira, 2009; Post et al. 2011; Bear et al., 2010; Fernandez-Feijoo et al., 2014; Al-Shaer and Zaman, 2016; Chen et al., 2016; Galbreath, 2016; Liao et al., 2015; Rao and Tilt, 2016; Saeed et al., 2016). This is because diversity among board directors improves the chances that different knowledge domains, perspectives and ideas will be considered in the decision-making process (Post et al., 2011; Liao et al., 2015). The board of directors is primarily responsible for monitoring the behaviour of management (Fama and Jensen, 1983). Board directors are also participating more actively in decision making about corporate environmental policies (Kassinis and Vafeas, 2002). Boards influence firm performance (Peng, 2004), strategic decision making (Golden and Zajac, 2001; Jensen and Zajac, 2004; Westphal and Fredrickson, 2001), internationalization strategies (Datta, et al., 2009), R\&D investment strategies (Kor, 2006), share price (Filatotchev and Bishop, 2002), CSR (Frias-Aceituno et al., 2013; Post et al., 2011), sustainability reporting (Amran et al., 2014; Al-Shaer and Zaman, 2016) and corporate governance (Farber, 2005; Monem, 2014).

Board gender diversity could improve the quality of board discussions and increase the ability of the board to provide better oversight of the firm's disclosures and reports. It could also reduce board effectiveness by increasing internal divisiveness and constraining its ability to act (Gul et al., 2011). The study of Lückerath-Rovers (2009) indicate that the presence of female directors on company boards provides legitimacy to the outside world regarding the company's values on diversity. Saeed et al. (2016) observe that board gender diversity is positively related to the firm size, and it is inversely related to corporate risk across both emerging and developed economies. Galbreath (2016) suggests based on secondary data from Australia's largest firms that the resources of outsiders and women on boards appear to complement each other in impacting on CSR. Al-Shaer and Zaman, (2016) find that gender diverse boards are associated with higher quality sustainability reports and independent 
female directors have greater effect on sustainability reporting quality than male directors. Chen et al. (2016) suggest that female directors improve board effectiveness in risk management with respect to R\&D investment. Rao and Tilt (2016) observe that board composition seems to be a major factor which can be assumed to have some influence on both CSR activities and CSR reporting. The study of Bear et al. (2010) extends current theory by demonstrating that the number of women on the board has a positive relationship with the strength ratings for CSR. Saeed et al. (2016) note that board gender diversity is positively related to the firm size, and it is inversely related to corporate risk across both emerging and developed economies.

There are also differences in the company board of directors' decision making, including CSR policies, due to its gender composition (Fernandez-Feijoo et al., 2014). Introducing gender diversity to corporate boards also has important implications for board dynamics (Ruigrok et al., 2007). Women bring different characteristics to boards where they are perceived to have a more participative, democratic, and communal leadership style (Eagly et al., 2003; Eagly and Johnson 1990; Rudman and Glick 2001). This may lead to improve board effectiveness as a result of the improved quality of board deliberations and better supervision of the firm's disclosures (Gul et al., 2011). Gul et al. (2011) argue that genderdiverse boards improve the quality of public disclosure through better monitoring. The current literature also suggests that female directors provide greater oversight and monitoring of managers' actions and reports (Hillman et al., 2007; Adams and Ferreira, 2009) through promoting better board attendance, assuming monitoring positions on audit, nominating, and corporate governance committees, and demanding greater accountability from managers for poor performance (Gul et al., 2011). Gender diversity has also been found to facilitate creativity within groups (Hoffman and Maier, 1961; Nemeth, 1986). By taking a broader view, the board will have a better understanding of the complexities of the business 
environment and thus improve decision-making. A more gender diverse board may also improve a firm's competitive advantage if it improves the firm's image (Campbell and Mínguez-Vera, 2008).

Academic research has advanced gender board composition from different perspectives and with different results. A comprehensive discussion, especially about women directors on corporate boards, is included in the study of Terjesen et al. (2009). Their study supports the position that women directors contribute to important firm level outcomes since they play direct roles as leaders, mentors, and network members as well as indirect roles as symbols of opportunity for other women. They inspire them to achieve and stay with their firms. Willims (2003) finds that female directors may be more inclined to use the firm's profit to help others, i.e. engage in charitable giving activities based on 185 Fortune 500 companies in 1994. Webb (2004) tests the effect of gender composition of the board on a range of measures of social responsibility including environmental responsiveness. Adams and Ferreira (2009) suggests that female directors have a significant impact on board governance, i.e. board inputs and firm outcomes based on 1,939 firms for the period 1996-2003. Post et al., (2011) find that the boards with a higher proportion of outsiders and those with three or more female directors have more favourable environmental disclosure strength scores, based on a sample of 78 companies (only electronic and chemical) that were on the list of 2006 and 2007 Fortune 1000 companies. The study by Liao et al. (2015) suggests that the small number of female directors make a difference in GHG disclosure decisions in the sample of the 329 largest companies in the United Kingdom based on 2011 CDP data.

Given the evidence, some scholars have argued that women's more protective attitude toward the environment is due to their reproductive role, while others have argued that, as a group, women may be more aware of environmental exploitation because of their experience in a cultural system of paternalistic exploitation (Wehrmeyer and McNeil, 2000). A large body of 
evidence supports the view that women are more concerned than men about perceived health and environmental risks (Bord and O'Connor, 1997; Davidson and Freudenburg, 1996). Accumulated research findings show that women tend to express higher levels of concern about technology and the environment than do men (Davidson and Freudenburg, 1996). Moreover, women receive more positive rewards than men for altruistic behaviour including caring and concern for others (Gilligan, 1982). The topic of female intelligence was addressed in $19^{\text {th }}$ century psychology via phrenology and the neuroanatomists (Shields, 1975). Haier et al. (2005) study finds that on neuroanatomical basis, the general level of intelligence is the same in men and women. However, the psychology of women in acquiring the character of an academic entity was witnessed by the proliferation of research on sex differences (Shields, 1975). Women are typically socialized into communal values reflecting a concern for others, selflessness, and a desire to be at one with others. Men are usually socialized into agentic values involving self-expansion, self-assertion, competence and mastery (Eagly, 1987). As a result, women tend to be more aware and concerned than men about the links between environmental harm and personal well-being (Stern et al., 1993).

It has also been argued that women's experience of motherhood gives them a heightened sense of morality that contributes to a more responsible and ethical use of power and authority (Sinclair, 1998). In this regard, in the typical masculine environments driven by competition, individualism, hierarchy and technical outcomes, feminine values are commonly viewed as being based on mutual empowerment, empathy and authenticity (Dillard and Reynolds, 2008). Tremblay et al. (2016) argue that if such gender-based sensitivity and skills really exist, then the economic logic of efficiency should lead businesses to diversify their boards' gender composition. In addition, a meta-analysis of gender differences in moral orientation (Jaffee and Hype, 2000) shows that women are somewhat more likely than men to use care reasoning. However, men and women use similar principles of fairness and equity 
(Post et al., 2011). It can be argued, therefore, female participation in the boardroom increases the likelihood of voluntary disclosure of climate change-related risks in the CDP. Therefore, the main hypothesis is stated as follows:

H1: There is a positive relationship between gender diversity and carbon disclosure score.

\subsection{Size of the Board of Directors:}

Board of directors have recently received considerable attention, in both practitioner and academic venues (Fama and Jenson, 1983; Baysinger and Butler, 1985; Boeker and Goodstein, 1991; Goodstein and Boeker, 1991; Daily and Dalton, 1994a, 1994b; Hillman et al., 2000; Adams and Ferreira, 2007; Rose, 2007; Prado-Lorenzo and Garcia-Sanchez, 2010; Liao et al., 2015 and Ben-Amar et al., 2015). The board of directors plays a key role in monitoring management and in constructing mechanisms that align managers' objectives with shareholders' interests (Armstrong et al., 2015). They also play a crucial role in corporate policy formulation, as well as its implementation and reviews (William, 2003). From an institutional perspective, larger boards are assumed to be beneficial (Judge and Zeithaml, 1992). Jensen (1993) argues that boards with more than about seven to eight members are unlikely to be effective.

The allocation of decision (or control) rights within an organization is a fundamental building block of organizational structure (Jensen and Meckling, 1990). Therefore, the size of board is important because larger boards are more likely to include more qualified directors (in terms of education and business experience) and, therefore, allow board members to offer the management high-quality advice (Zahra and Pearce, 1989). Lu et al. (2015) argue that this could contribute to the firm's image and relationships with stakeholders. However, their findings do not support that hypothesis. Nevertheless, scholars have found a larger board to be better (Gales and Kesner, 1994; Dalton et al., 1999). In this case, the climate change risk issue could be considered by larger number of board members as their background skills 
(education, experience) help of understanding and evaluating a firm's social roles ( Chang et al., 2015). They can bring a wealth of knowledge and experience to the board and can also increase the element of independence and objectivity in the board's strategic decision-making (Fama and Jensen, 1983). Having more directors also increases the pool of expertise and advice that executives can capitalize on. Pfeffer and Salancik (1978) contend that "for proponents of resource dependency, larger boards increase the company's ability to deal with environmental uncertainty and to form links with business partners” (p. 172). Ruigrok et al. (2006) argue that if environmental complexity and uncertainty have risen, boards have to deal with higher information-processing demands. They find that one way of meeting this demand is to enlarge the board size. In our context, CPD's concerned with global warming or reduction of GHG emissions, firms need to invest in green technology in order to create longterm economic value through energy savings and improved environmental image. Therefore, carbon pollution control is largely considered a social responsibility (Liao et al., 2015) and the directors' collective decisions (Luo and Tang, 2014). These observations imply that having larger number of directors on a board with diversified directors' knowledge could limit the board's ability to contribute to the strategy development process. This leads us to our second hypothesis.

H2: There is a positive relationship between board size and carbon disclosure score.

\subsection{CEO duality}

The situation where the CEO is also the chairman of the board is called CEO duality (Ruigrok et al., 2006; Rechner and Dalton, 1991). From an agency perspective (Fama, 1980), CEO duality involves an inherent role conflict for the CEO-chair and enhances the power of the CEO relative to the board. This compromises the board's functions of monitoring and disciplining the CEO (Tang, 2016). Boards of directors are charged with ensuring that CEOs carry out their duties in a way that serves the best interests of shareholders (Finkelstein and 
D'aveni, 1994). Duality offers the clear direction of a single leader, and a resulting faster response to external events (Boyd, 1995, p. 301). Proponents of duality also characterise the board chair position as 'being relatively less powerful and more ceremonial and symbolic than the CEO's position' (Harries et al., 1988, p. 214). In a review of the CEO duality literature, Krause et al. (2015, p. 268) conclude that "the literature has produced almost no evidence suggesting that CEO duality reduces a board's ability to hold its CEO accountable". The literature also suggests that duality enables the CEOs to pursue their own agenda due to greater power and influence over firm decision-making. However, that power does not reduce their vulnerability to dismissal (Martin et al., 2017). As a key organizational decision maker, CEOs evidently hold greater accountability and take initiative regarding corporate social responsibility policies (Oh et al., 2014). It is also likely that CEO duality increases the CEO's bargaining power (Monem, 2013).

However, agency theory is more critical towards CEO duality (Ruigrok et al., 2006). Their assumptions rely on three issues: first, the CEO-chairman is responsible for organizing board meetings which gives the CEO a significant influence on the meeting agenda and on the information provided to directors (Pearce and Zahra, 1991). Second, duality gives the CEO more influence on the nomination of new directors or executives (Westphal and Zajac, 1995). Third, as companies face increasing environmental instability, the separation of the two roles might be one way to cope with higher information processing demands. Therefore, if a CEO is too powerful it hinders outside directors from opposing and challenging strategic propositions of the CEO (Golden and Zajac, 2001). We, therefore, argue that a strong CEO arising from the CEO duality will have a negative impact on strategic board involvement and we arrive at our third hypothesis.

H3: There is a negative relationship between CEO duality and the carbon disclosure score. 


\section{Research Design}

\subsection{Sample and Data}

We use CDP's data together with firm characteristics and corporate governance data for 2011 to 2013 for companies by searching the Bloomberg data set. Several previous research studies on the CDP database were completed for the 2007 to 2010 time period. Our sample is extended to the 2011-2013 periods. The total observations for the three year period are 1175 companies. However, based on corporate governance and firm characteristics data availability for the model, our sample includes 331 companies from 10 industry sectors in 33 countries with firms in 12 geographical locations (see Appendix). Table 1 shows the sample size and the sample selection procedures for the study.

Table 1: Sample size and sample selection

\begin{tabular}{lll}
\hline Number of firms available in the CDP data set (2011-13) & 1175 & \\
Less, Missing data for empirical tests & 844 & \\
Total number of firms in the sample & 331 & Percentage \\
\hline Industry sector & No. of firms & 15.10 \\
\hline Consumer discretionary & 50 & 11.77 \\
Consumer staples & 39 & 4.83 \\
Energy & 16 & 15.70 \\
Financials & 52 & 10.87 \\
Health care & 36 & 11.77 \\
Industrials & 39 & 15.40 \\
Information technology & 51 & 1.21 \\
Telecommunication services & 04 & 7.00 \\
Materials & 23 & 6.35 \\
Utilities & 21 & 100 \\
Total & 331 & \\
\hline
\end{tabular}

\section{Research Design and Variables}

\section{1 Model}

We test the hypotheses of this study by employing the main regression model as below. Table 2 provides a description/definition of our dependent, independent, and control variables. 


$$
\mathrm{CDP} \text { Score }=\alpha+\beta_{1} \mathrm{WOB}+\beta_{2} \mathrm{BSIZE}+\beta_{3} \mathrm{CEODU}+\beta_{4} \mathrm{BOM}+\beta_{5} \mathrm{TOBQ}+\beta_{6} \mathrm{ROA}+\beta_{7}
$$

$$
\mathrm{R} \& \mathrm{D}+\beta_{8} \mathrm{ENGC}+\beta_{9} \mathrm{TAS}+\varepsilon
$$

\begin{tabular}{|c|c|c|}
\hline \multicolumn{3}{|l|}{$\begin{array}{l}\text { Dependent variable } \\
\text { CDP Score: The compar }\end{array}$} \\
\hline Independent variables & Sign & Definition \\
\hline WOB & + & Number of women directors in the board \\
\hline BSIZE & + & Number of members in the board \\
\hline CEODU & - & If CEO is the chair of the board of directors \\
\hline \multicolumn{3}{|l|}{ Control variables } \\
\hline BOM & + & $\begin{array}{l}\text { Number of board meetings held during the calendar } \\
\text { year }\end{array}$ \\
\hline TOBQ & + & $\begin{array}{l}\text { Tobin's Q is the total market value of the company } \\
\text { based on the year end price and the number of shares } \\
\text { outstanding, plus preferred stock, book value of long } \\
\text { term debt and current liabilities, divided by the book } \\
\text { value of total assets. }\end{array}$ \\
\hline ROA & + & Return of asset \\
\hline $\mathrm{R} \& \mathrm{D}$ & + & $\begin{array}{l}\text { Research \& development expenditure divided by total } \\
\text { asset }\end{array}$ \\
\hline ENGC & + & Amount of energy consumed by a particular firm \\
\hline TAS & + & Natural logarithm of the company's total assets \\
\hline
\end{tabular}

Table 2: Description of dependent, independent and control variable and expected sign

\section{2 Dependent variable}

This study uses the carbon disclosure scores of the Carbon Disclosure Project (CDP) from 2011 to 2013 (inclusive). We have selected the CDP as the base of our sample given the fact that the CDP is an independent non-profit entity that facilitates the collection of emissionrelated data for institutional investors and they provide data for major global companies. The CDP was formulated in response to institutional shareholder requests for firm-specific greenhouse gas (GHG) information. Each year, CDP asks the top executive managers of the world's largest public companies to disclose information about the risks and opportunities posed by climate change, the strategies being pursued to address them, and company-wide 
greenhouse gas emissions. Their questionnaire focuses on how the company is affected by global warming or by the need to reduce its emissions of GHG. The CDP questionnaire covers five sections: Risks and Opportunities, Emissions Accounting, Verification and Trading, Carbon Reduction Performance, and Climate Change Governance (CDP Report, 2013). The disclosure score assesses the completeness and quality of a company's response. Its purpose is to provide a summary of the extent to which companies have answered CDP's questions in a structured format. A high disclosure score signals that a company provided comprehensive information about the measurement and management of its carbon footprint, its climate change strategy and risk management processes and outcomes (CDP Report, 2015). A score (from 0 to 100) is applied to most of the company responses to the CDP, which are assessed for disclosure and performance. On the basis of firm response, the CDP prepares a carbon disclosure score (CDS) which is publicly available.

\section{3 Independent and control variables}

The main variable of interest of the study is women directors on the board (WOB) and their influence on CDP disclosure. Our sample includes only firms having women's presence on corporate boards to observe their specific effects on CDP disclosure after separating from firms without women director on the board. Therefore, our focus is particularly on the role of women on the board in the climate change disclosure. Since women on the board (WOB) is integral part of the board structure, without the functions of the board women director cannot influence or make a difference in decision making process. The number of female directors and their share among board members are important in this regard to play a role along with other members in the board including the $\mathrm{CEO}$ being the chairman of the board. CEO with chairman role attached becomes more powerful than any other board members. Therefore, we have included both board size (BSIZE) and CEO duality (CEODU) as independent variables in the regression model to see whether women directors' role on CDP disclosure is mediated 
by other board variables or not. As such hypotheses are developed for these three independent variables in reference to related literature in Section 3.

In regards to control variables, previous studies (Waddock and Graves, 1997; Brammer and Millington, 2009; Bear et al., 2010; Galbreath, 2011; Post et al., 2011; Setó-Pamies, 2015) argue that firm size and profitability, can exert influence on a firm's responsible behaviour. We control firm size (TAS) and profitability (ROA and TOBQ) variables in our study. Firm size is controlled with a measurement of total tangible assets, and is transformed logarithmically due to the positively skewed distribution. The firm's success is explained by its performance over a certain period of time (Bauwhede, 2009). There is evidence that a firm's financial performance strongly influences its level of social responsibility. This is because a firm with higher profits also has more resources to spend on the quantity and quality of carbon disclosure (Brammer and Pavelin, 2006). According to slack resources theory (Waddock and Graves 1997), higher levels of CSR might be driven by better financial conditions such as high profitability. In contrast, Tobin's Q refers to a market value measure of expected long-run firm performance (Bozec et al., 2010). ROA only reflects past corporate performance. However, Tobin's Q has the advantage of reflecting shareholders' share. This makes it easier to compare companies which reflect future profit through an evaluation of investors (Chung and Pruitt, 1994). We, therefore, include this control variable because it is forward-looking and is a reflection of the expectations of the shareholders concerning the firm's future performance (Hutchinson and Gull, 2004) and corporate social accountability.

Frequency of board meetings may have an impact on monitoring and strategic decisions about carbon emissions. They also allow more time for directors to confer, set strategy, and monitor management. If firms have fewer board meetings than are necessary, by overemphasizing costs, board meeting frequency will be positively associated with firm value (Vafeas, 1999). Conger et al. (1998) also suggest that board meeting time is an important 
resource in improving the board's effectiveness. $R \& D$ is included as control variable by considering how the R\&D fits within the firm's overall activities, and by revealing the firm's strategic vision (Entwistle, 1999). It also reflects the extent of information asymmetry associated with R\&D (Aboody and Lev, 2000). We also include ENGC (energy consumption) as a control variable. This is because it is assumed that economic growth depends on energy consumption (Shen and Sun, 2016). The external pressures that are often considered as motivation for firms to adopt environmental management practices (Gualandris and Kalchschmidt, 2014) and in order to comply with regulatory requirements (Jones, 2010) they are grouped into three different institutional isomorphic categories: coercive pressure (Zhu et al., 2007), mimetic pressure (Jorgensen et al., 2010; Liu et al., 2013) and normative pressure (Zhang et al., 2012; Zhang, Wang \& Lai, 2015). In addition, in order to balance economic and environmental performance in response to these external pressures, many industrial firms have recognized the importance of being low-carbon and environmentallyproactive by developing and implementing so-called 'green' strategies (Fisher-Vanden and Thorburn, 2011; Gale, 2006).

\section{Results and discussion}

\section{1 Univariate results and discussion}

Table 3 presents descriptive statistics of CDP score, corporate governance and financial variables. It can be seen in Table 3 that the average CDP scores are 75.45, indicating high score for the sample firms. The average board size is 12 members, which is relatively high, with maximum of 25 and minimum 5 members. The women on the boards account for an average of 2 members of our sample with maximum 7 and minimum 1 member, which is much higher than the figure of 1 reported by Prado-Lorenze and Garcia-Sanchez (2010) in 2007 CDP data. While CEO duality is 33\%, i.e. one-third of the sample firms have CEOchair duality, the average board meeting is 10 times in a year. In regards to profitability, TOBQ is high while ROA is relatively low at around $7 \%$ on average. The R\&D mean value is 
$\$ 102,722.67$ million while total asset is $6,880,000.00$ million and the average energy consumption is $\$ 32,976$ thousands ton.

Table 3: Descriptive statistics

\begin{tabular}{|l|c|c|c|c|c|}
\hline Variables & Mean & Median & SD & Min & Max \\
\hline CDP & 75.45 & 80.00 & 19.14 & 0.00 & 100.00 \\
\hline WOB & 2.36 & 2.00 & 1.18 & 1.00 & 7.00 \\
\hline BSIZE & 12.41 & 12.00 & 3.03 & 5.00 & 25.00 \\
\hline CEODU & 0.33 & 0.00 & 0.47 & 0.00 & 1.00 \\
\hline BOM & 9.72 & 8.00 & 7.03 & 1.00 & 12.00 \\
\hline ROA & 6.63 & 5.32 & 6.47 & -24.41 & 54.72 \\
\hline TOBQ & 1.76 & 1.36 & 1.17 & 0.54 & 10.26 \\
\hline R\&D (in million \$) & 102722.67 & 1182.50 & 874207.83 & 0.30 & 14800000.00 \\
\hline ENGC ( in thousands Ton) & 32976.14 & 3266.34 & 90513.39 & 9.39 & 778758.00 \\
\hline TAS ( in Million \$) & 6880000.00 & 91192.00 & 43200000.00 & 3248.40 & 733000000.00 \\
\hline
\end{tabular}

Table 4 provides the correlation matrix. The results of pair-wise correlation for CDP score and all other variables indicate that multicollinearity is not present. This is because the highest significant correlation coefficient is 0.36 between women on board (WOB) and board size (BSIZE). According to the table, BSIZE, WOB, CEODU, and BOM variables have significant positive correlations with the dependent variable CDP score at a $1 \%$ level except CEODU which is significant at the 5\% level. Since WOB and BSIZE are positively associated with CDP score, it indicates that women on board and board size have positive effects on firms in dealing with environmental issues and/or climate change related-risk and, therefore, participating in the CDP project. However, it is not clear here how CEO duality can positively influence social responsibility. The other two performance characteristics variables, ROA and TOBQ, are negatively correlated with CDP score. It may be the case that carbon emission task is expensive for the sample firms, given that the average ROA is 6.63 in Table 3. Although average TOBQ is at good share (i.e. 1.76) in Table 3, market investors may not response positively to firm's carbon emission activities because of the associated cost issue. 
Table 4 Correlation Matrix:

\begin{tabular}{|c|c|c|c|c|c|c|c|c|c|c|}
\hline & CDP & BSIZE & WOB & CEODU & ROA & TOBQ & R\&D & ENGC & Log TAS & BOM \\
\hline CDP & 1.000 & & & & & & & & & \\
\hline BSIZE & $0.095 * * *$ & 1.000 & & & & & & & & \\
\hline WOB & $0.123 * * *$ & $0.362 * * *$ & 1.000 & & & & & & & \\
\hline CEODU & $0.057 * *$ & -0.036 & 0.026 & 1.000 & & & & & & \\
\hline ROA & $-0.075 * * *$ & $-0.227 * * *$ & $-0.107 * * *$ & 0.016 & 1.000 & & & & & \\
\hline TOBQ & -0.013 & $-0.232 * * *$ & $-0.077 * * *$ & 0.022 & 0.743 & 1.000 & & & & \\
\hline ENGC & 0.043 & -0.010 & -.035 & $0.075 * * *$ & $-0.089 * * *$ & $-0.175 * * *$ & 1.000 & & & \\
\hline R\&D & 0.001 & -0.046 & 0.022 & 0.035 & $0.1524 * * *$ & $0.248 * * *$ & $-0.243 * * *$ & 1.000 & & \\
\hline $\begin{array}{l}\text { Log } \\
\text { TAS }\end{array}$ & -0.039 & $0.068 * * *$ & 0.034 & $-0.100 * * *$ & $-0.289 * * *$ & $-0.377 * * *$ & $-0.186^{* * *}$ & $0.092 * * *$ & 1.000 & \\
\hline $\mathrm{BOM}$ & $0.119 * * *$ & $0.1352 * * *$ & $0.101 * * *$ & -0.376 & $-0.075 * * *$ & $-0.111 * * *$ & $-0.316^{* * *}$ & 0.049 & $0.220 * * *$ & 1.000 \\
\hline
\end{tabular}
at the $10 \%$ level

\section{2 Multivariate regression results and discussion}

The model is estimated using the fixed-effects estimator since OLS generally leads to biased estimates of $\beta$ (Berkey et al., 1995). Table 5 below presents the regression results in 5 different models where Model 3 and Model 5 are the final models of the study denoting the explanatory power of the model in terms of $\mathrm{R}^{2}$ and F-statistics. In Model 1, we consider dependent variable CDP and the main variable of interest women on board (WOB) (i.e. CDP Score $=\alpha+\beta_{1}$ WOB). The results shows positive significant effect of women (WOB) on CDP disclosure, as predicated. In Model 2, we consider CDP and all control variables (i.e. $\mathrm{CDP}$ Score $\left.=\alpha+\beta_{1} \mathrm{BOM}+\beta_{2} \mathrm{TOBQ}+\beta_{3} \mathrm{ROA}+\beta_{4} \mathrm{R} \& \mathrm{D}+\beta_{5} \mathrm{ENGC}+\beta_{6} \mathrm{TAS}+\varepsilon\right)$, which indicates CDP is positive significantly influenced by Tobin's Q (TOBQ) and firm size (TAS) and negatively, though weak, by profitability (ROA). In Models 3, we combine Model 1 and Model 2 to observe the effect of WOB on CDP in the presence of control variables (i.e. $\mathrm{CDP}$ Score $=\alpha+\beta_{1} \mathrm{WOB}+\beta_{2} \mathrm{BOM}+\beta_{3} \mathrm{TOBQ}+\beta_{4} \mathrm{ROA}+\beta_{5} \mathrm{R} \& \mathrm{D}+\beta_{6} \mathrm{ENGC}+\beta_{7}$ TAS $+\varepsilon$ ). Our results confirm significant positive effect of women (WOB) on CDP disclosure, as reported in Model 1. Therefore, hypothesis 1 (H1) is accepted, based on theoretical directions in Section 2.

Since women on board is integral part of the board, it is important to see their impact on CDP disclosure still exist as the same in the presence of other board members as well as CEO's 
dual role as chairman of the board or mediated by other board variables. So, in Models 4 , we extend Model 1 by adding board size and CEO duality variables (i.e. CDP Score $=\alpha+\beta_{1}$ $\left.\mathrm{WOB}+\beta_{2} \mathrm{BSIZE}+\beta_{3} \mathrm{CEODU}\right)$. The findings remain consistent for WOB showing positive significant effect on CDP disclosure, while contrary to expectation negative significant effect of board size (BSIZE) on CDP and no effect of CEO duality (CEODU) are evident. These results indicate that WOB's role on CDP disclosure is not mediated or influenced by other board variables. Women directors can take stand in favour of CDP independently. However, we find a strong negative significant relationship between board size (BSIZE) and CDP, although following the literature we expected more board members will support more CDP disclosure. The CEO duality (CEODU) also reveals insignificant result, though with negative sign, while we expected that strong CEO in chairman role of the board would restrain CDP disclosure. Thus, hypothesis $(\mathrm{H} 2)$ and hypothesis $3(\mathrm{H} 3)$ are rejected.

Table 5: Fixed effects regression results

\begin{tabular}{|c|c|c|c|c|c|}
\hline & Model 1 & Model 2 & Model 3 & Model 4 & Model 5 \\
\hline Determinant & & Coefficient & Coefficient & Coefficient & Coefficient \\
\hline Constant & $\begin{array}{c}67.7362 * * * \\
(0.7616)\end{array}$ & $\begin{array}{c}-229.2455^{* * *} \\
(74.7298)\end{array}$ & $\begin{array}{c}-167.2564 * * \\
(84.3860)\end{array}$ & $\begin{array}{c}107.8108 * * * \\
(14.9204)\end{array}$ & $\begin{array}{l}-80.257 \\
(76.390)\end{array}$ \\
\hline WOB & $\begin{array}{c}3.6368 * * * \\
(1.8944)\end{array}$ & & $\begin{array}{l}2.0868^{* *} \\
(1.0211)\end{array}$ & $\begin{array}{c}3.9862 * * * \\
(0.6791)\end{array}$ & $\begin{array}{c}3.0490 * * * \\
(1.0262)\end{array}$ \\
\hline BSIZE & & & & $\begin{array}{c}-16.19 * * * \\
(5.955)\end{array}$ & $\begin{array}{l}-14.421^{*} \\
(8.2132) \\
\end{array}$ \\
\hline CEODU & & & & $\begin{array}{c}-0.2225 \\
(2.52)\end{array}$ & $\begin{array}{c}1.4599 \\
(3.6830)\end{array}$ \\
\hline $\mathrm{BOM}$ & & $\begin{array}{l}-1.8384 \\
(3.0255) \\
\end{array}$ & $\begin{array}{l}-0.0047 \\
(0.1415) \\
\end{array}$ & & $\begin{array}{l}-0.4115 \\
(0.1476) \\
\end{array}$ \\
\hline ROA & & $\begin{array}{l}-0.2928^{*} \\
(0.1787) \\
\end{array}$ & $\begin{array}{l}-0.3179^{*} \\
(0.1789) \\
\end{array}$ & & $\begin{array}{l}-0.2717 \\
(0.1731) \\
\end{array}$ \\
\hline TOBQ & & $\begin{array}{c}9.5193 * * * \\
(2.1722) \\
\end{array}$ & $\begin{array}{c}8.7145 * * * \\
(2.2593) \\
\end{array}$ & & $\begin{array}{c}9.2446 * * * \\
(2.2706) \\
\end{array}$ \\
\hline ENGC & & $\begin{array}{c}1.2696 \\
(4.2497) \\
\end{array}$ & $\begin{array}{c}1.2652 \\
(4.5859) \\
\end{array}$ & & $\begin{array}{c}0.0032 * * * \\
(0.000)\end{array}$ \\
\hline $\mathrm{R} \& \mathrm{D}$ & & $\begin{array}{l}-185.9579 \\
(135.8817)\end{array}$ & $\begin{array}{l}-179.3969 \\
(134.0988)\end{array}$ & & $\begin{array}{c}1.3185 \\
(0.9642)\end{array}$ \\
\hline TAS & & $\begin{array}{c}24.8940 * * * \\
(6.3217) \\
\end{array}$ & $\begin{array}{c}19.924 * * * \\
(7.6217)\end{array}$ & & $\begin{array}{l}14.755 * * \\
(6.6439) \\
\end{array}$ \\
\hline & $\begin{array}{c}\mathrm{R}^{2}=0.04 \\
F \text {-statistic: } \\
6.39 \\
\mathrm{P}=0.000\end{array}$ & $\begin{array}{c}\mathrm{R}^{2}=0.16 ; \\
F \text {-statistic: } \\
5.81 ; \mathrm{P}= \\
0.000\end{array}$ & $\begin{array}{c}\mathrm{R}^{2}=0.16 \\
F \text {-statistic: } \\
5.68 \\
\mathrm{P}=0.000\end{array}$ & $\begin{array}{c}\mathrm{R}^{2}=0.05 \\
F \text {-statistic: } \\
6.45 ; \mathrm{P}=0.000\end{array}$ & $\begin{array}{c}\mathrm{R}^{2}=0.26 \\
F \text {-statistic: } \\
7.36 ; \mathrm{p}=0.000\end{array}$ \\
\hline
\end{tabular}


Finally, in Model 5, we extend Model 4 by adding all control variables to observe individual effect of each independent variable on CDP. The regression results confirm that WOB has significant positive association with CDP score, which is consistent with the result in the in Models 1, 3 and 4. Thus, $\mathrm{H} 1$ is supported, indicating that women in the boardroom increases the voluntary disclosure of climate change-related disclosure in the CDP project, which is consistent with previous studies of CSR or sustainability (Chang et al., 2015; Set-Pamies, 2015; Post, et al., 2011; Prado-Lorenzo and García-Sanchez, 2010; Bear et al., 2010). This result confirms the theoretical arguments that women tend to be economically less selfinterested than men (Ibrahim and Angelidis, 1995); and their presence favours problem solving, increases leadership effectiveness, and fosters efficiency in the establishment of global relationships (Adams and Ferreira, 2009; Robinson and Dechant, 1997). This focuses on gender diversity implicit to accounts emphasizing social networks (Westphal and Milton, 2000), Critical Mass Theory (Kramer et al., 2006; Bear et al., 2010) and team dynamics (Woolley et al., 2010; and Hoogendoorn et al., 2013). The spin-off benefits arising from diversity include enhanced monitoring, more incisive decision-making and greater transparency (McGuinness, et al., 2016).

Further, in Model 5 we find a negative but weak significant relationship between CDP and board size (BSIZE), as compared to Model 4. So, H2 is not supported. Jensen (1993) suggests that board size is negatively related to the ability of the board to pursue long term strategic goals. Jensen (1993) also suggests that the board of directors can do their tasks effectively when the board size is not more than seven or eight members. In our study, average size of the board is 12 and due to this reason, board size is negatively associated with CDP score. In order words, it suggests that it is difficult for a large board to co-ordinate and be involved in strategic decision-making (Bonn et al., 2004). Moreover, Lindgreen et al. (2010), who found that boards do not have a significant influence on the extent of CSR disclosures. As 
climate change related risk decisions involve with firms long term strategic goals, therefore, it is likely that the small size of board is effective in social and environmental strategic decision-making. Firstenberg and Malkiel (1994, p. 34), contend that a small board size of eight or fewer members 'engenders focus, participation, and genuine interaction and debate' for directors to advise management on company issues which satisfied under agency perspective (Ong and David, 2008). Again, in Model 5, the CEO duality (CEODU) shows insignificant result though with positive sign against negative sign in Model 4 , that is no association with the CDP score as found in Model 4. So H3 is also not supported. This means that CEODU is less prevalent in making decisions on climate change related-risk issues in our sample firms. Taken overall, our results suggest that a woman on board (WOB) has strong positive significant association with CDP disclosure but board size and CEO duality have not.

In regards to control variables in Model 5, it is noted that the coefficient of board meetings (BOM) is not significant, suggesting that there is no direct link between the overall activities of the board and carbon disclosure. This is also supported by Liao et al. (2015) who notice that it is true even in the presence of environmental committee. Firm size (TAS) is positive and significant. It is assumed that due to their scale, large firms are more visible, perceived to be more polluting, and thus are more likely to be expected to engage in environmental related reporting (Hackston and Milne, 1996). Results also show that R\&D is insignificant. However, ENGC and TOBQ are positively significant at level $1 \%$. The reason for insignificant R\&D is that it is neither related to the climate change issue nor has involvement to create or invest in any technology to reduce carbon emissions. It is also interesting that ENGC (energy consumption) is positive and significant with CDP score. This indicates that firms with an energy consumption policy are more concerned with environmental issues and as a result, they are willing to respond to the CDP project. TOBQ is positively significant, meaning that 
market-based profitable firms are concerned with climate change-related risks, although accounting-based profitability (ROA) is not significant. However, it does indicate that profitability is a factor in taking any decisions, especially those related to climate and environmental issues.

\section{Conclusion}

The motivation for this study is to examine how the gender composition (women on board) affect corporate climate change related disclosure. Our paper examines the effect of gender diversity on Carbon Disclosure Project (CDP) score/index, in particular the impact of women on corporate boards (WOB) on carbon emission disclosure (CDP) from a global perspective of 33 countries for the period of 2011-2013. As we mentioned earlier that CDP project has been working since 2000 on climate change risks and opportunities and there are currently 5,500 companies that disclose to CDP covering climate change related disclosure including global warming, greenhouse emissions, water and forest-risk commodities (CDP Report, 2015), therefore, board composition seems to be a major factor which can be assumed to have some influence on both CSR and CSR reporting (Rao and Tilt, 2016) as well as the climate change related risk issue.

We document that woman on board plays a vital role in CDP disclosure. Our study extends current theory, in particular resource dependence theory, by demonstrating that the presence of women on the board has a positive relationship with the CDP score. The strong explanatory power of WOB on CDP disclosure provides evidence of need for gender diversity in corporate boards. Our study is, therefore, unique in identifying the corporate characteristics for addressing the CDP's climate change program. Again, we report that board size (BSIZE) has negative significant effect on CDP while CEO duality (CEODU) has no real effect. In regards to control variables, we find market-based financial performance Tobin's Q (TOBQ), energy consumption (ENGC) and firm size (TAS) appear to have positive 
significant effect on CDP disclosure, however, board meetings (BOM), research and development (R\&D) and accounting-based profitability (ROA) indicate no explanatory power on CDP.

Our empirical results have certain policy implications that shed light on how to upgrade the response to these issues. Our findings also have important implications for instituting good corporate governance and in particular, gender diversity. The outcome of our analysis advocates that companies that include women directors with a larger board size, may expect to achieve better carbon performance and voluntarily disclose of the level of carbon information requested by the CDP. The study of Luo and Tang (2014) also indicates that good governance performers in the market are more forthright in reporting their commitment to carbon control using the CDP disclosure code. Therefore, our study is relevant to investors and other stakeholders in evaluating the accountability of companies in relation to strategies for managing climate risk. This study also offers policy makers' insights into corporate governance practices in relation to global warming risks and opportunities in order to meet the needs of a low-carbon economy. Because, good corporate governance practices lead to reduced agency costs, and good governance performance is likely to disclose more and distinguish themselves for their investors and other stakeholders (Clarkson et al., 2008; AlTuwaijri et al., 2004). In fact, corporate governance mechanisms are usually design to protect both shareholders and stakeholders interests in the firms. Our study supports both resource dependence and stakeholder theories that boards of directors serve as a linking mechanism between companies and their stakeholders, and that they provide legitimacy to different stakeholder groups in the society. The positive impact of gender diversification is significant as having women directors who can enhance critical analysis in board decision making process. Our results contribute to the growing body of literature highlighting the importance 
of board diversity and governance variables when considering climate change related risk issue at the firm level.

As with all empirical research, this study is not without limitations. First, the study sample was composed of CDP data which include 10 different industry sectors, though diversity of board may be different by the nature of industry. However, we did not control this industry sector variable. Future research can be expanded to examine women on board against industry nature of the firms, i.e. sensitive industry, for example health care firm, mining etc. Second, we do not consider the effect on CDP scores each year against number of women increases in the board room. Third, due to non-availability of data for large number of countries, we did not classify women directors as independent or non- independent, so further research can be extended by considering directors who may be classified as independent but who are actually affiliated with the firm through prior employment or ongoing business relations.

Note:

In this article, we interchange different terms of climate change related risk such as CSR, social responsibility, carbon emission, GHG and sustainability, which ultimately concretely covers all aspects of climate changes. The same concept is also supported by Prado-Lorenzo and Garcia-Sanchez (2010).

\section{References}

Aboody, D. and Lev, B. (2000), "Information asymmetry, R\&D, and insider gains," The Journal of Finance, Vol. 55 No. 6, pp. 2747-2766.

Adams, R. B., and Ferreira, D. (2009), "Women in the boardroom and their impact on governance and performance”, Journal of Financial Economics, Vol. 94 No. 2, pp. 291-309. 
Adams, R.B., and Ferreira, D. (2007), "A theory of friendly board”, Journal of Finance. 62 , $217-250$.

Adger, W. N., Huq, B, K., Conway, D. and Hulme, M. (2003), “Adaptation to climate change in the developing world", Progress in Development Studies, Vol. 3 No.3, pp. 179-195.

Allen, M. R., Frame, D. J., Huntingford, C., Jones, C. D., Lowe, J. A., Meinshausen, M., and Meinshausen, N. (2009), "Warming caused by cumulative carbon emissions towards the trillionth tonne", Nature, Vol. 458 No. 7242, pp. 1163-1166.

Al-Shaer, H., Zaman, M. (2016), "Board gender diversity and sustainability reporting quality", Journal of Contemporarv Accounting \& Economics, Vol. 12 No.3, pp. 210-222.

Amran, A., Lee, S. P., and Devi, S. S. (2014), "The influence of governance structure and strategic corporate social responsibility toward sustainability reporting quality", Business Strategy and the Environment, Vol. 23 No. 4, pp. 217-235.

Armstrong, C., Guay, W. R., Mehran, H., \& Weber, J. (2016), "The Role of Financial Reporting and Transparency in Corporate Governance", Economic Policy Review, Vol. 22, No. 1, pp.107-128.

Al-Tuwaijri, S.A., Christensen, T.E., Hughes, E. (2004), "The relations among environmental disclosure, environmental performance, and economic performance: a simultaneous equations approach", Accounting Organisations and Society, Vol. 29 No. 5, pp. 447-471.

Bauwhede, H. V. (2009), "On the relation between corporate governance compliance and operating performance", Accounting and Business Research, Vol. 39 No. 5, pp. 497-513.

Baysinger, B. D., and Butler, H. N. (1985), "Corporate governance and the board of directors: Performance effects of changes in board composition", Journal of Law, Economics, and Organization, Vol.1 No.1, pp. 101-124. 
Ben-Amar, W., Chang, M., and McIlkenny, P. (2015), "Board gender diversity and corporate response to sustainability initiatives: Evidence from the carbon disclosure project", Journal of Business Ethics, pp. 1-15. DOI: 10.1007/s10551-015-2759-1.

Bear, S., Rahman, N., and Post, C. (2010), "The impact of board diversity and gender composition on corporate social responsibility and firm reputation", Journal of Business Ethics, Vol. 97 No. 2, pp. 207-221.

Berkey, C. S., Hoaglin, D. C., Mosteller, F., and Colditz, G. A. (1995), “A random-effects regression model for meta-analysis" Statistics in Medicine, Vol. 14 No. 4, pp. 395-411.

Bernardi R. (2006), “Associations between Hofstede's cultural constructs and social desirability response bias", Journal of Business Ethics, Vol. 65 No. 1, pp.43-53.

Boeker, W., and Goodstein, J. (1991), "Organizational performance and adaptation: Effects of environment and performance on changes in board composition", Academy of Management Journal, Vol. 34 No. 4, pp. 805-826.

Bianco, M., Ciavarella, A., and Signoretti, R. (2015), "Women on corporate boards in Italy: the role of family connections", Corporate Governance: An International Review, Vol. 23 No. 2, pp. 129-144.

Bord, R. J., and O' Connor, R. E. (1997), "The gender gap in environmental attitudes: the case of perceived vulnerability to risk", Social Science Quarterly, Vol. 78, No. 4, pp. 830840.

Boyd, B. K. (1995), “CEO duality and firm performance: A contingency model”, Strategic Management Journal, Vol. 16 No.4, pp. 301-312.

Bøhren, Ø., and Staubo, S. (2016), "Mandatory gender balance and board independence" European Financial Management, Vol. 22, No. 1, pp. 3-30. 
Bocken, N. M. P., and Allwood, J. M. (2012), "Strategies to reduce the carbon footprint of consumer goods by influencing stakeholders", Journal of cleaner production, Vol. 35, pp. 118-129.

Bozec, R., Dia, M., and Bozec, Y. (2010), “Governance-performance relationship: a reexamination using technical efficiency measures", British Journal of Management, Vol. 21 No. 3, pp. 684-700.

Brammer, S. and Millington, A. (2006), "Firm size, organizational visibility and corporate philanthropy: an empirical analysis" Business Ethics: A European Review, Vol.15 No. 1, pp. $6-18$.

Brammer, S. J., and Pavelin, S. (2006), "Corporate reputation and social performance: The importance of fit", Journal of Management Studies, Vol.43 No. 3, pp. 435-455.

Brown, W. O., Helland, E., and Smith, J. K. (2006), "Corporate philanthropic practices", Journal of Corporate Finance, Vol. 12 No.5, pp. 855-877.

Campbell, K., and Mínguez-Vera, A. (2008), "Gender diversity in the boardroom and firm financial performance", Journal of Business Ethics, Vol. 83 No. 3, pp. 435-451.

Carroll, A. B., and Buchholtz, A. K. (2000), "Society: Ethics and Stakeholder Management", $8^{\text {th }}$ ed. South-Western Cengage Learning, United States.

CDP (2013), "CDP S\&P 500 climate change report 2013”, available at https://www.ipcc.ch/pdf/assessment-report/ar5/wg1/WG1AR5_SummaryVolume_FINAL.pdf

CDP (2015), "CDP global climate change report 2015- at the tipping point", available at http://admin.indiaenvironmentportal.org.in/files/file/CDP-global-climate-change-report-2015.pdf

Chen, S., Ni, X., Tong, J. Y. (2016), "Gender diversity in the boardroom and risk management: A case of R\&D investment", Journal of Business Ethics, Vol. 136 No 3, pp. 599-621. 
Chung, K. H., and Pruitt, S. W. (1994), “A simple approximation of Tobin's q. Einancial management, Vol. 23 No. 3, pp. 70-74.

Ciocirlan, C., and Pettersson, C. (2012), "Does workforce diversity matter in the fight against climate change? An analysis of Fortune 500 companies", Corporate Social Responsibility and Environmental Management, Vol. 19 No. 1, pp. 47-62.

Clarkson, M. E. (1995), “A stakeholder framework for analyzing and evaluating corporate social performance", Academy of Management Review, Vol. 20 No. 1, pp. 92-117.

Clarkson, P.M., Li, Y., Richardson, G.D., and Vasvari, F.P., (2008), "Revisiting the relation between environmental performance and environmental disclosure: an empirical analysis", Accounting Organisations and Society, Vol. 33 No.4, pp. 303-327.

Conger, J. A., Finegold, D., and Lawler, E. E. (1998), “Appraising boardroom performance”, Harvard Business Review, Vol. 76, pp. 136-164.

Daily, C. M., Dalton, D. R., and Cannella, A. (2003), "Corporate governance: Decades of dialogue and data", Academy of Management Journal, Vol. 28 No. 3, pp. 371-382.

Daily, C. M., Certo, S. T., and Dalton, D. R. (1999), "Research notes and communications a decade of corporate women: Some progress in the boardroom, none in the executive suite", Strategic Management Journal, Vol. 20 No. 1, 93-99.

Daily, C. M., and Dalton, D. R. (1994a), "Bankruptcy and corporate governance: The impact of board composition and structure", Academy of Management Journal, Vol. 37 No. 6, pp. 1603-1617.

Daily, C. M., and Dalton, D. R. (1994b), "Corporate governance and the bankrupt firm: An empirical assessment”, Strategic Management Journal, Vol. 15 No. 8, pp. 643-654.

Dalton, D. R., Daily, C. M., Johnson, J. L., \& Ellstrand, A. E. (1999), "Number of directors and financial performance: A meta-analysis”, Academy of Management Journal, Vol. 42 No. 6, pp. 674-686. 
Datta, D. K., Musteen, M., \& Herrmann, P. (2009)' "Board characteristics, managerial incentives, and the choice between foreign acquisitions and international joint ventures", Journal of Management, Vol. 4 No. 2, pp. 321-338.

Davidson, D. J., and Freudenburg, W. R. (1996), "Gender and environmental risk concerns a review and analysis of available research", Environment and Behaviour, Vol. 28 No. 3, pp. 302-339.

Deegan, C. (2002), "Introduction: The legitimising effect of social and environmental disclosures - A theoretical foundation”, Accounting, Auditing and Accountability Journal, Vol. 15 No.3, pp. 282-311.

Demb, A. and Neubauer, F. (1992), "The corporate board: Confronting the paradoxes", Oxford University Press, New York.

Dillard, J. and Reynolds, M. (2008), "Green Owl and the Corn Maiden", Accounting, Auditing \& Accountability Journal, Vol. 21 No. 4, pp. 556-579.

Donaldson, T., and Preston, L. (1995), "The stakeholder theory of the corporation: Concepts, evidence, and implications", Academy of Management Review, Vol. 20 No. 1, pp. 65-91.

Eagly, A. H. (1987), "Reporting sex differences", American Psvchologist. Vol 42_No. 7, pp. 756-757

Eagly, A. H., Johannesen-Schmidt, M. C., and Van Engen, M. L. (2003), "Transformational, transactional, and laissez-faire leadership styles: A meta-analysis comparing women and men”, Psychological Bulletin, Vol.129 No. 4, pp. 569-591.

Eagly, A. H., and Johnson, B. T. (1990), "Gender and leadership style: A meta-analysis", Psychological Bulletin, Vol.108 No. 2, pp. 233-256.

Eesley, C., and Lenox, M. J. (2006). "Firm responses to secondary stakeholder action", Strategic Management Journal, Vol. 27 No. 8, pp. 765-781. 
Entwistle, G. M. (1999), "Exploring the R\&D disclosure environment", Accounting Horizons, Vol. 13 No. 4, pp. 323-342.

Fama, E. F. (1980), "Agency problems and the theory of the firm", Journal of Political Economy, Vol. 88, pp. 288-307.

Fama, E. F., and Jensen, M. C. (1983), "Separation of ownership and control”, Journal of Law and Economics, Vol. 26, No. 2, pp. 301-325.

Farber, D. B. (2005), "Restoring trust after fraud: Does corporate governance matter?", The Accounting Review, Vol. 80, No. 2, pp. 539-561.

Fernandez-Feijoo, B., Romero, S., and Ruiz-Blanco, S. (2014), "Women on boards: do they affect sustainability reporting?", Corporate Social Responsibility and Environmental Management, Vol. 21 No. 6, pp. 351-364.

Finkelstein, S., and D'aveni, R. A. (1994), "CEO duality as a double-edged sword: How boards of directors balance entrenchment avoidance and unity of command", Academy of Management Journal, Vol. 37 No. 5, pp. 1079-1108.

Fisher-Vanden, K., \& Thorburn, K. S. (2011), "Voluntary corporate environmental initiatives and shareholder wealth", Journal of Environmental Economics and Management, Vol. 62 No. 3, pp. $430-445$.

Frias-Aceituno, J. V., Rodriguez-Ariza, L., and Garcia-Sanchez, I. M. (2013), "The role of the board in the dissemination of integrated corporate social reporting", Corporate Social Responsibility and Environmental Management, Vol. 20, No. 4, pp. 219-233

Freeman, R. E. (2010), "Strategic management: A stakeholder approach", Cambridge University Press. 
Filatotchev, I., \& Bishop, K. (2002), "Board composition, share ownership, and 'underpricing' of UK IPO firms”, Strategic Management Journal, Vol. 23 No. 10, pp. 941955.

Fuente, J. A., García-Sánchez, I. M., and Lozano, M. B. (2017), "The role of the board of directors in the adoption of GRI guidelines for the disclosure of CSR information", Journal of Cleaner Production, Vol. 141, pp. 737-750.

Galbreath, J. (2016), "Is Board Gender Diversity Linked to Financial Performance?: The Mediating Mechanism of CSR”, Business \& Society, DOI: 10.1177/0007650316647967.

Galbreath, J. (2011), “Are there gender-related influences on corporate sustainability? A study of women on boards of directors" Journal of Management \& Organization, Vol. 7 No. 1, pp. 17-38.

Gale, R. (2006), "Environmental management accounting as a reflexive Modernization strategy in cleaner production", Journal of Cleaner Production, Vol. 14 No. 14, pp. 12281236.

Gales, L. M., and Kesner, I. F. (1994), “An analysis of board of director size and composition in bankrupt organizations", Journal of Business Research, Nov. 30 No. 3, p. 271-282.

Glass, C., Cook, A., and Ingersoll, A. R. (2015), "Do women leaders promote sustainability? Analyzing the effect of corporate governance composition on environmental performance" Business Strategy and the Environment, DOI: 10.1002/bse.1879.

Goodstein, J. and Boeker, W. (1991), "Turbulence at the top: a new perspective on governance structure changes and strategic change", Academy of Management Journal, Vol. 34 No. 2 pp. 306-330.

Golden, B. R., and Zajac, E. J. (2001). When will boards influence strategy? Inclination power equals strategic change", Strategic Management Journal, Vol. 22 No. 12, pp. 10871111. 
Gray, R., Owen, D., and Adams, C. (1996). Accounting \& accountability: changes and challenges in corporate social and environmental reporting. Prentice Hall.

Gilligan, C. (1982), "In a different voice: Psychological theory and women's development”, Harvard University Press, Cambridge, MA.

Gualandris, J., and Kalchschmidt, M. (2014), “Customer pressure and innovativeness: their role in sustainable supply chain management", Journal of Purchasing and Supply Management, Vol. 20 No. 2, pp. 92 -103.

Guenther, E. M., and Hoppe, H. (2014), "Merging Limited Perspectives", Journal of Industrial Ecology, No. 18 No. 5, pp. 689-707.

Guenther, E., Guenther, T., Schiemann, F., and Weber, G. (2016), "Stakeholder Relevance for Reporting Explanatory Factors of Carbon Disclosure", Business and Society, Vol. 55, No. 3, pp. 361-397.

Gul, F. A., Srinidhi, B., and Ng, A. C. (2011), "Does board gender diversity improve the informativeness of stock prices?", Journal of Accounting and Economics, Vol. 51 No. 3, pp.314-338.

Hackston, D. and Milne, M.J. (1996), "Some determinants of social and environmental disclosures in New Zealand companies", Accounting, Auditing \& Accountability Journal, Vol. 9 No. 1, pp. 77-108.

Haque, S., and Deegan, C. (2010), "Corporate Climate Change-Related Governance Practices and Related Disclosures: Evidence from Australia”, Australian Accounting Review, Vol. 20, No. 4, pp. 317-333.

Harrison, J. R., Torres, D. L., and Kukalis, S. (1988), "The changing of the guard: Turnover and structural change in the top-management positions", Administrative Science Quarterly, Vol. 33, pp. 211-232. 
Haier, R. J., Jung, R. E., Yeo, R. A., Head, K., and Alkire, M. T. (2005), “The neuroanatomy of general intelligence: sex matters", NeuroImage, Vol. 25, No.1, pp. 320-327.

Hill, C. W., and Jones, T. M. (1992), "Stakeholder-agency theory", Journal of Management Studies, Vol. 29 No. 2, pp. 131-154.

Hillman, A. J., Cannella, A. A., and Paetzold, R. L. (2000), "The resource dependence role of corporate directors: Strategic adaptation of board composition in response to environmental change", Journal of Management Studies, Vol. 37 No. 2, pp. 235-256.

Hillman, A. J., Shropshire, C., and Cannella, A. A. (2007), "Organizational predictors of women on corporate boards", Academy of Management Journal, Vol. 50 No. 4, pp. 941-952.

Hoogendoorn, S., Oosterbeek, H., and Van P. M. (2013), “The impact of gender diversity on the performance of business teams: Evidence from a field experiment", Management Science, Vol. 59 No. 7, pp. 1514-1528.

Hoang, T. C., Abeysekera, I., and Ma, S. (2016), "Board Diversity and Corporate Social Disclosure: Evidence from Vietnam”, Journal of Business Ethics, DOI: 10.1007/s10551-016$3260-1$

Hoffman, A. J. (2005), "Climate change strategy: The business logic behind voluntary greenhouse gas reductions", California Management Review, Vol. 47 No. 3, pp. 21-46.

Hoffman, L. R., and Maier, N. R. (1961), "Quality and acceptance of problem solutions by members of homogeneous and heterogeneous groups", The Journal of Abnormal and Social Psychology, Vol. 62 pp. 401-407.

Huang, C. L., and Kung, F. H. (2010), "Drivers of environmental disclosure and stakeholder expectation: Evidence from Taiwan", Journal of Business Ethics, Vol. 96 No. 3, pp. 435451.

Hutchinson, M., and Gul, F. A. (2004), "Investment opportunity set, corporate governance practices and firm performance", Journal of Corporate Finance, Vol. 10 No. 4, pp. 595-614. 
Intergovernmental Panel on Climate Change.(1996), “Climate change 1995: The science of climate change. New York : Cambridge University Press.

IPCC, (2013), "Climate Change 2013 -The Physical Science Basis, Intergovernmental Panel on Climate Change", available on https://www.ipcc.ch/pdf/assessmentreport/ar5/wg1/WG1AR5_SummaryVolume_FINAL.pdf.

Islam, A. M., and Deegan, C. (2008), "Motivations for an organisation within a developing country to report social responsibility information: evidence from Bangladesh", Accounting, Auditing and Accountability Journal, Vol. 21 No. 6, pp. 850-874.

Jaffe, S. and Hyde, J. S. (2000), "Gender differences in moral orientation: A meta-analysis", Psychological Bulletin, No. 126 No. 6, pp. 703-726

Jamali, D. (2008), "A stakeholder approach to corporate social responsibility: A fresh perspective into theory and practice”, Journal of Business Ethics, Vol. 82 No 1, pp. 213-231.

Jensen, M. (1993), "The modern industrial revolution, exit, and the failure of internal control systems", Journal of Finance, Vol. 48 No. 3, pp. 831-880.

Jensen, M., Meckling, W. (1990), "Specific and general knowledge, and Organizational structure. Werin, L. and H. Wijkander (eds.), 1992, Contract Economics, Blackwell, Oxford, pp. 251-274.

Jensen, M., \& Zajac, E. J. (2004), “Corporate elites and corporate strategy: How demographic preferences and structural position shape the scope of the firm", Strategic Management Journal, Vol. 25 No. 6, pp. 507-524.

Jones, C. (2010), "Exploring new ways of assessing the effect of regulation on environmental management", Journal of Cleaner Production, Vol. 18, No. 13, pp. 1229 -1250. 
Jørgensen, M. S., Jørgensen, U., Hendriksen, K., Hirsbak, S., Thomsen, H. H., and Thorsen, N. (2010), "Environmental management in Danish transnational textile product chains", Management Research Review, Vol. 33 No.4, pp. 357-379.

Judge, W. Q. Jr and Zeithaml, C. P. (1992). "Institutional and strategic choice perspectives on board involvement in the strategic decision making process", Academy of Management Journal, Vol. 35, No.4, pp.766-94.

Kassinis, G., and Vafeas, N. (2002). "Corporate boards and outside stakeholders as determinants of environmental litigations", Strategic Management Journal, Vol. 23, pp. 399415.

Kolk, A., and Pinkse, J. (2007). "Multinationals' political activities on climate change", Business and Society, Vol. 46 No. 2, pp. 201-228.

Kolk, A., Levy, D., and Pinkse, J. (2008), "Corporate responses in an emerging climate regime: the institutionalization and commensuration of carbon disclosure", European Accounting Review, Vol. 17 No. 4, pp. 719-745.

Kor, Y. Y. (2006), "Direct and interaction effects of top management team and board compositions on R\&D investment strategy", Strategic Management Journal, No. 27 No. 11, pp. 1081-1099.

Kramer, V.W., Konrad, A.M., Erkut, S. (2006), "Critical mass on corporate boards" Why three or more women enhance governance, Report No. WCW 11, Wellesley Centers for Women Working Paper Series, Wellesley, MA.

Krause, R., Priem, R., and Love, L. (2015), "Who's in charge here? Co-CEOs, power gaps, and firm performance", Strategic Management Journal, Vol. 36 No. 13, pp. 2099-2110.

Lash, J. and Wellington, F. (2007), “Competitive advantage on a warming planet”, Harvard Business Review, Vol. 85 No. 3, pp. 94-104. 
Lashof, Daniel A., and Dilip R. Ahuja (1990), "Relative contributions of greenhouse gas emissions to global warming", Vol. 344 No. 6266, pp. 529-531.

Liao, L., Luo, L., \& Tang, Q. (2015), “Gender diversity, board independence, environmental committee and greenhouse gas disclosure", The British Accounting Review, Vol. 47 No. 4, pp. $409-424$.

Lückerath-Rovers, Mijntje (2009). "Female directors on corporate boards provide legitimacy to a company: A resource dependency perspective",

Luo, L., and Tang, Q. (2014a), "Does voluntary carbon disclosure reflect underlying carbon performance?", Journal of Contemporary Accounting and Economics, Vol. 10 No. 3, pp. 191-205.

Luo, L., and Tang, Q. (2014b), "Carbon tax, corporate carbon profile and financial return", Pacific Accounting Review, Vol. 26 No. 3, pp. 351-373.

Lu, Y., Abeysekera, I., and Cortese, C. (2015). "Corporate social responsibility reporting quality, board characteristics and corporate social reputation: evidence from China", Pacific Accounting Review, Vol. 27, No. 1, pp. 95-118.

Luo, L., Lan, Y. C., and Tang, Q. (2012), "Corporate incentives to disclose carbon information: Evidence from the CDP Global 500 report", Journal of International Financial Management and Accounting, Vol. 23 No. 2, 93-120.

Lindgreen, A., Swaen, V., and Campbell, T. T. (2010), "Corporate social responsibility practices in developing and transitional countries: Botswana and Malawi", Journal of Business Ethics, Vol. 90 No. 3, pp. 429-440.

Mahadeo, J. D., Oogarah-Hanuman, V., and Soobaroyen, T. (2011), "Changes in social and environmental reporting practices in an emerging economy (2004-2007): Exploring the relevance of stakeholder and legitimacy theories", Accounting Forum, Vol. 35, No. 3, pp. $158-175$. 
Martin, G. P., Wiseman, R. M., \& Gomez-Mejia, L. R. (2017), "The Interactive Effect of Monitoring and Incentive Alignment on Agency Costs", Journal of Management, forthcoming.

McFarland, J. M. (2008), "Warming up to climate change risk disclosure", Fordham Journal of Corporate and Financial Law", Vol 14 No. 3, pp. 281-323.

McGuinness, P. B., Vieito, J. P., and Wang, M. (2016), "CSR performance in China: The role of board gender and foreign ownership", Journal of Corporate Finance. DOI: 10.1016/j.jcorpfin.2016.11.001

McWilliams, A., and Siegel, D. (2001), "Corporate social responsibility: A theory of the firm perspective", Academy of Management Review, Vol. 26, No. 1, pp. 117-127.

Mitchell, R., Agle, B., and Wood, D. (1997), “Toward a theory of stakeholder identification and salience: Defining the principle of who and what really counts", Academy of Management Review, Vol. 22 No. 4, pp. 853-886.

Monem, R. M. (2013), "Determinants of board structure: Evidence from Australia”, Journal of Contemporary Accounting and Economics, Vol. 9 No. 1, pp. 33-49.

Nalikka, A. (2009), "Impact of gender diversity on voluntary disclosure in annual reports", Accounting and Taxation, Vol. 1 No.1, pp. 101-113.

Nemeth, C. J. (1986), "Differential contributions of majority and minority influence", Psychological Review, Vol. 93 No. 1, pp. 23-32.

Neville, B. A., Bell, S. J., \& Whitwell, G. J. (2011), "Stakeholder salience revisited: Refining, redefining, and refueling an underdeveloped conceptual tool", Journal of Business Ethics, Vol. 102 No. 3, pp. 357-378. 
Nielsen, S., and Huse, M. (2010), "The contribution of women on boards of directors: Going beyond the surface", Corporate Governance: An International Review, Vol. 18, No. 2, pp. 136-148.

Oh, W. Y., Chang, Y. K., \& Cheng, Z. (2016), "When CEO career horizon problems matter for corporate social responsibility: The moderating roles of industry-level discretion and blockholder ownership", Journal of Business Ethics, Vol. 133, No .2, pp. 279-291.

Ogbechie, C., Koufopoulos, D. N., and Argyropoulou, M. (2009), "Board characteristics and involvement in strategic decision making: The Nigerian perspective", Management Research News, Vol. 32 No. 2, pp. 169-184.

Ong, C. H. and David Wan , (2008), "Three conceptual models of board role performance”, Corporate Governance: The international journal of business in society, Vol. 8 No 3 pp. 317 $-329$.

Parker, L. D. (2005), "Social and environmental accountability research: A view from the commentary box", Accounting, Auditing and Accountability Journal, Vol. 18 No. 6, pp. 842860.

Patten, D. M. (2002), “The relation between environmental performance and environmental disclosure: a research note", Accounting, organizations and Society, No. 27 No. 8, pp. 763 773.

Pearce, J. A. II and Zahra, S. A. (1991), "The relative power of CEOs and boards of directors: associations with corporate performance", Strategic Management Journal, Vol. 12, No. 2, pp. $135-53$.

Peng, M. W. (2004), "Outside directors and firm performance during institutional transitions", Strategic Management Journal, Vol. 25 No 5, pp. 453-471. 
Prado-Lorenzo, J. M., and Garcia-Sanchez, I. M. (2010), "The role of the board of directors in disseminating relevant information on greenhouse gases", Journal of Business Ethics, Vol. 97 No. 3, pp. 391-424.

Post, C., Rahman, N., and Rubow, E. (2011), “Green governance: Boards of directors' composition and environmental corporate social responsibility", Business and Society, Vol. 50 No. 1, pp. 189-223.

Pfeffer, J., and Salancik, G. R. (1978), "The external control of organizations: A Resource dependence perspective", New York, NY: Harper and Row.

Rao, K., Tilt, C. (2016), "Board composition and corporate social responsibility: The role of diversity, gender, strategy and decision making", Journal of Business Ethics, Vol. 138 No 2, pp. 327-347.

Ratnatunga, J., Jones, S., and Balachandran, K. R. (2011), "The valuation and reporting of organizational capability in carbon emissions management", Accounting Horizons, Vol. 25, No. 1, pp. 127-147.

Rankin, M., Windsor, C. and Wahyuni, D. (2011), “An investigation of voluntary corporate greenhouse gas emissions reporting in a market governance system: Australian evidence", Accounting, Auditing and Accountability Journal, Vol. 24 No.8, pp. 1037-1070.

Rechner, P. L., and Dalton, D. R. (1991), "CEO duality and organizational performance: a longitudinal analysis”, Strategic Management Journal, Vol. 12, No. 2, pp.155-160.

Reid, E. M., and Toffel, M. W. (2009), "Responding to public and private politics: Corporate disclosure of climate change strategies”, Strategic Management Journal, Vol. 30 No. 11, pp. 1157-1178.

Robinson, G., and Dechant, K. (1997), "Building a business case for diversity", The Academy of Management Executive, Vol. 11, No. 3, pp. 21-31. 
Roberts, R. W. (1992). Determinants of corporate social responsibility disclosure: An application of stakeholder theory. Accounting, Organizations and Society, Vol. 17 No. 6, pp. 595-612.

Rose, C. (2007), "Does female board representation influence firm performance? The Danish evidence", Corporate Governance: An International Review, Vol. 15 No. 2, pp. 404-413.

Rudman, L. A., \& Glick, P. (2001), "Prescriptive gender stereotypes and backlash toward agentic women", Journal of Social Issues, Vol. 57 No. 4, pp. 743-762.

Ruigrok, W., Peck, S., and Tacheva, S. (2007), "Nationality and gender diversity on Swiss corporate boards", Corporate Governance: An International Review, Vol. 15 No. 4, pp. 546557.

Ruigrok, W., Peck, S. I., and Keller, H. (2006), "Board characteristics and involvement in strategic decision making: Evidence from Swiss companies", Journal of Management Studies, Vol. 43, No. 5, pp. 1201-1226.

Schaltegger, S., and Burritt, R. (2000), “Contemporary environmental accounting: issues, concepts and practice”, Greenleaf Publishing.

Setó-Pamies, D. (2015), “The relationship between women directors and corporate social responsibility", Corporate Social Responsibility and Environmental Management, Vol. 22 No. 6, pp. 334-345.

Shields, S. (1975), "Functionalism, Darwinism, and the psychology of women", American Psychologist, Vol. 30 No. 7, pp. 739-754.

Shen, L., and Sun, Y. (2016), "Review on carbon emissions, energy consumption and lowcarbon economy in China from a perspective of global climate change", Journal of Geographical Sciences, Vol. 26 No. 7, pp. 855-870.

Sinclair, A. (1998), "Doing Leadership Differently", Melbourne: Melbourne University Press. 
Søgaard Jørgensen, M., Jørgensen, U., Hendriksen, K., Hirsbak, S., Holmlund Thomsen, H., and Thorsen, N. (2010), "Environmental management in Danish transnational textile product chains", Management Research Review, Vol. 33 No. 4, pp. 357-379.

Stern, P. C., Dietz, T., and Kalof, L. (1993), "Value orientations, gender, and environmental concern", Environment and Behavior, Vol. 25 No. 5, pp. 322-348.

Strand, R. (1983), “A systems paradigm of organizational adaptations to the social environment", Academy of Management Review, Vol. 8, No.1, pp. 90-96

Tang, J. (2016), "CEO duality and firm performance: The moderating roles of other executives and blockholding outside directors", European Management Journal. http://dx.doi.org.libraryproxy.griffith.edu.au/10.1016/j.emj.2016.05.003

Tang, Q., and Luo, L. (2014), "Carbon management systems and carbon mitigation", Australian Accounting Review, Vol. 24 No. 1, pp. 84-98.

Terjesen, S., Sealy, R., and Singh, V. (2009), "Women directors on corporate boards: A review and research agenda", Corporate Governance: An International Review, Vol. 17 No. 3, pp. 320-337.

Torchia, M., Torchia, M., Calabrò, A., and Calabrò, A. (2016), "Board of directors and financial transparency and disclosure. Evidence from Italy", Corporate Governance, Vol. 16 No. 3, pp. 593-608.

Tremblay, M. S., Gendron, Y., and Malsch, B. (2016), “Gender on board: deconstructing the 'legitimate' female director”, Accounting, Auditing \& Accountability Journal, Vol. 29 No. 1, pp.165-190.

Ullmann, A. A. (1985), "Data in search of a theory: A critical examination of the relationships among social performance, social disclosure, and economic performance of US firms", Academy of Management Review, Vol. 10, No. 3, pp. 540-557. 
Vafeas, N. (1999), "Board meeting frequency and firm performance", Journal of Financial Economics, Vol. 53 No. 1, pp. 113-142.

Waddock, S. A., and Graves, S. B. (1997), "The corporate social performance-financial performance link", Strategic Management Journal, Vol. 18 No. 4, pp. 303-319.

Webb E. (2004), “An examination of socially responsible firms' board structure”, Journal of Management and Governance, Vol. 8 No. 3, pp. 255-277.

Wehrmeyer, W., and McNeil, M. (2000)”, “Activists, pragmatists, technophiles and treehuggers? Gender differences in employees' environmental attitudes", Journal of Business Ethics, No. 28 No. 3, pp. 211-222.

Westphal, J. D., and Fredrickson, J. W. (2001), "Who directs strategic change? Director experience, the selection of new CEOs, and change in corporate strategy", Strategic Management Journal, Vol. 22 No. 12, pp. 1113-1137.

Westphal, J. D. and Zajac, E. J. (1995). "Who shall govern? CEO/boardpower, demographicsimilarity, and new director selection”, Administrative Science Quarterly, 40, pp. 60-83.

Westphal, J.D., Milton, L.P., (2000), "How experience and network ties affect the influence of demographic minorities on corporate boards", Administrative Science Quarterly, 45, pp. 366-398.

Williams, R. J. (2003), "Women on corporate boards of directors and their influence on corporate philanthropy", Journal of Business Ethics, Vol. 42 No. 1, pp. 1-10.

Woolley, A.W., Chabris, C.F., Pentland, A., Hashmi, N., and Malone, T.W. (2010), "Evidence for A collective intelligence factor in the performance of human groups", Science, Vol. 330, pp. 686-688. 
Zahra, S. A., and Pearce, J. A. (1989), "Boards of directors and corporate financial performance: A review and integrative model", Journal of Management, Vol. 1, No. 2, pp. 291-334.

Zhang, B., Wang, Z., and Lai, K. H. (2015), “Mediating effect of managers' environmental concern: Bridge between external pressures and firms' practices energy conservation in China", Journal of Environmental Psychology, Vol. 43, pp. 203-215.

Zhang, N., Wang, B., and Chen, Z. (2016), "Carbon emissions reductions and technology gaps in the world's factory, 1990-2012”, Energy Policy, Vol. 91, pp. 28-37.

Zhang, B., Wang, Z., Yin, J., and Su, L. (2012), "CO 2 emission reduction within Chinese iron \& steel industry: practices, determinants and performance", Journal of Cleaner Production, Vol.33, pp. 167-178.

Zhu, Q., Sarkis, J., and Lai, K. (2007), “Green supply chain management: pressures, practices and performance within the Chinese automobile industry", Journal of Cleaner Production, Vol. 15, pp. 1041-1052. 




(c) Emerald Publishing Limited

This is a pre-print of a paper and is subject to change before publication. This pre-print is made available with the understanding that it will not be reproduced or stored in a retrieval system without the permission of Emerald Publishing Limited. 